\title{
Research on Informationization Talented Person Training Pattern of the Countryside Area in China
}

\author{
Yang Wang ${ }^{1}$ and Zhongwei Sun ${ }^{2, *}$ \\ ${ }^{1}$ Institute for Tourism Studies, Hebei Normal University, 050031 Shijiazhuang, China \\ ${ }^{2}$ Department of Resource \& Environment, Shijiazhuang College, 050035 Shijiazhuang, China \\ sunzhongwei@126.com
}

\begin{abstract}
In profits from the domestic and foreign successfull experience fully, this paper creates an informationization talented person training pattern of the countryside area in China which includes the leadership training stage, the information officer training stage and the populace popular stage, and explains the training main body, the training object and the training way and so on. In order to carry on this pattern healthily and effectively, this paper proposes six big principles that should be persisted, namely the principle of adjusting measures to local conditions and the prominent characteristic, innovation methods and the principle of stressing practical results, combination of regular and nonperiodical training, centralism training and long-distance training, participation of international society and the relevant enterprise, schools and students.
\end{abstract}

Keywords: Countryside area, Countryside informationization, Talented person training, Pattern, China.

\section{Introduction}

The countryside informationization refers to realize popular applying degree and the process about the modern information technology in countryside production circulation, management and operation, culture and education, social management, public service and so on through strengthening countryside information infrastructure constructions, such as broadcasting television network, telecommunication network and computer network, using and exploiting information resources to the full and constructing the information service system to promote information communication and knowledge sharing (Li,2009). The countryside informationization construction in China has made the remarkable progress. China will realize the goal that $100 \%$ of administrative villages can telephone to each other and $100 \%$ of villages and towns can access the internet in 2010. Up to the point, the countryside informationization in China, especially the network infrastructure construction has taken initial shape, the information supplies mechanism of government and the telecommunication enterprise was consummating gradually. At the same time, web cam scale of China's countryside has achieved $106,810,000$ and the popular rate enhances to $15 \%$. At present, how to train to the web cam and the non-web cam in the countryside area and enhance

\footnotetext{
* Corresponding author .
} 
their information accomplishment to dock informationization supplies effectively is becoming a key question of countryside informationization.

\section{Informationization Personnel Training Pattern of the Countryside Area in China}

The informationization personnel training in China's countryside area must experience three stages approximately which both to distinguish mutually in the content and to intercross in the time, namely the leadership training stage, the information officer training stage and the populace training stage (to see Fig.1).

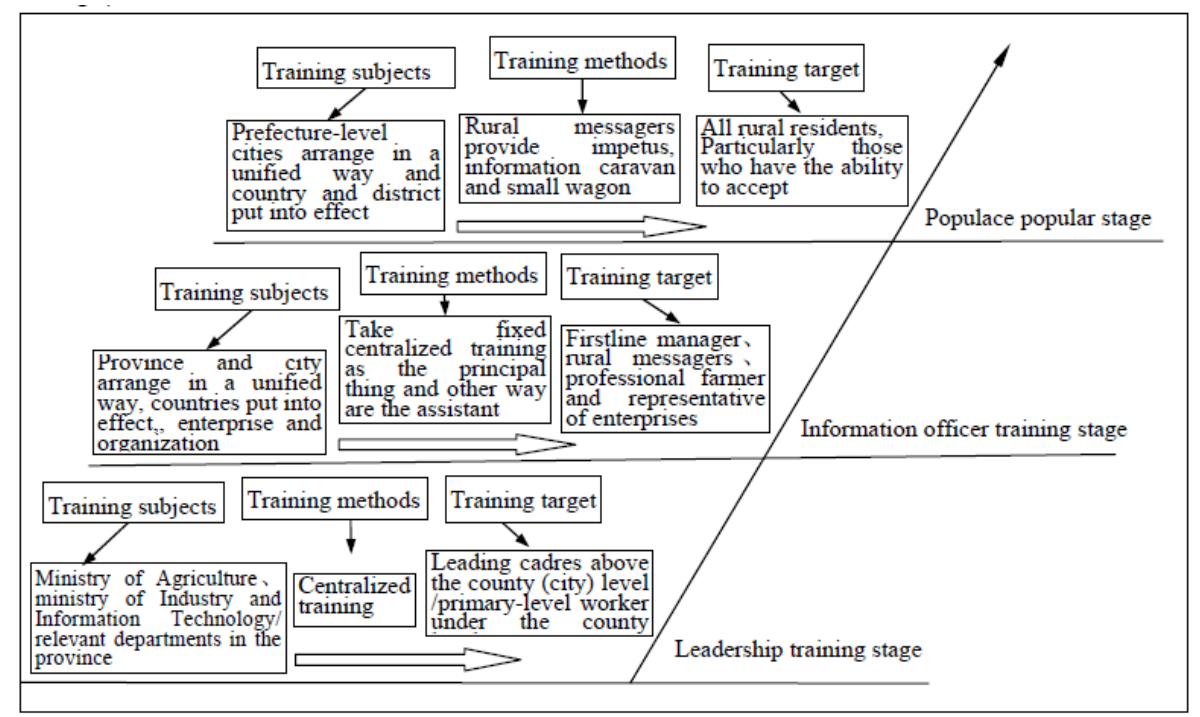

Fig. 1. The informationization personnel training pattern in Chinese countryside area

\subsection{Leadership Training Stage}

The leadership training stage belongs to the first stage of the informationization personnel training in countryside.Because the time of informationization construction in Chinese countryside is not long, and the renewal of the information technology is very quick, new objects and situations appear constantly in the construction process. The administrative cadre of countryside informationization which works for the government department should often be trained. The main body of state-level training is the National Ministry of Agriculture, the Industry and the Informationization Department, the main object is the leading cadre of countryside informationization which are above the level conforms to the training request of national city or county, and the way is unifies centralism training, the training expense is undertaken by the country. Such as the leading cadre training class of national countryside which was conducted in Weihai by the Industry and the Informationization Department in October, 2008 
and the construction and development training class of agricultural countryside informationization which was conducted in Beijing by the Ministry of Agriculture in October, 2009, they have trained respectively different ranks of leadership. The main body of provincial level training is the related department in provinces, the object is the basic unit informationization staff in information manages of the counties, the towns and villages with far teaching to manage and so on, the main way is also unifies centralism training. Through the training, the countryside informationization staffs which work for the government can increase their information accomplishment effectively, then they will have the ability to direct the practice of local countryside informationization in a scientific way.

\subsection{Information Officer Training Stage}

The information officer training stage belongs to the second stage of countryside informationization personnel training, and is also the main body of the countryside informationization training in China at present. The information officer who can provide the agriculture information service in the countryside and the main item enterprise of industrial production, the wholesale market of agricultural product, and the staff in the intermediary organization. The countryside information officer is the bridge and ligament in connecting the information service organization in basic unit of agriculture and farmers, and to strengthen the construction of countryside information officer troop is the effective way to solve the question about "the last kilometer" in information service. The main body of information officer training stage can be organized by the provinces and cities level, such as the information officer's training in informationization demonstration village which belongs to provincial and municipality level in informationization preliminary stage, but mainly be organized and implemented by the County Agricultural Bureau. Besides all levels of administrative department, it may mobilize the domestic telecommunication operation business and the overseas IT enterprise fully (for example Microsoft, AMD and so on), as well as the positive participation of European Union and International Organization. The key of each place must focus on the countryside information service manager, the kind of person which raises wealthy and powerful family, the main item enterprise in agricultural industrial production, the wholesale market of agricultural product, the intermediary organization as well as to develop the countryside information officer in cadres of village and group, and to carry on through fixed-point centralism training and the modern distance learning and other ways auxiliarily. At last, the countryside information officer who has finished the training and verification will be awarded the countryside information officer credentials which are inspected by the province agriculture department (bureau, committee) and printed uniformly by the Ministry of Agriculture.

\subsection{Populace Popular Stage}

The populace popularize stage is the last stage of countryside informationization personnel training, and is also the symbol of countryside informationization construction which has reached the maturity. The training of this stage can be arranged by the locally administered level and implemented by the organization in counties, towns and villages. The objects of training are all inhabitants, the key point is people who have the good accepting ability and the degree of education above the junior middle school. The training way may be mainly carried on through the countryside 
information officer in information service station of villages and small towns, and the big or small information boxcar is also the quite good way in addition. The big information boxcar is the private car which is made to implement countryside informationization knowledge training and popularize countryside computer knowledge training through science, technology, information and the application training in a body by the Information Industrial Department. There are 15 computers, projecting apparatus and printer and so on in the vehicle, it has the wired and the wireless surfer function, and is a mobile technology training classroom and the information service station. The scale of small information boxcar must be small and be equipped with 1 driver, 1 propaganda work personnel, as well as notebook computer, projecting apparatus and turning on equipment of internet in common. The function of big or small information boxcar is especially remarkable, especially in districts of imperfect construction of information service station and inconvenient area of the personnel fixed point centralism training.

\section{Basic Principle of Informationization Personnel Training of Countryside in China}

\subsection{Principle of Acting as Circumstances Permits with the Prominent Characteristic}

In the informationization personnel training of countryside in China, it must persist throughout acting as circumstances permit with the prominent characteristic principle. Firstly, the national territory in China is vast, there are big differences in terrain landform, informationization foundation, economy level of development, population characteristic, scientific cultural quality in the east, the middle, the west as well as the northeast area, therefore it needs to choose various suitable ways of informationization personnel training in provinces according to their own situation. Secondly, even if in the same province, it also has the big difference among local countrysides, and it also needs to make informationization personnel training plan according to act as circumstances permit formulation. Besides acts as circumstances permit, in this local countryside informationization personnel training, it may highlight its own characteristic, this characteristic itself is also the result of acting as circumstances permit to formulate the policies and measures. Only to insist on the acting as circumstances permit with the prominent characteristic principle, it can discover and determine the personnel training pattern which mostly suits the local countryside informationization, and obtain the desired effect in practice.

\subsection{Principle of Innovation Ways and Emphasizing Actual Effect}

The information society is a new form of society. A lot of things are totally new which include the informationization construction in countryside and many other things, therefore we should carry on our work creatively. The training pattern of the informationization personnel needs be innovated constantly with the help of the successful experience of the foreign countries. The concrete innovation way may include the training main body, the object, the way, the place and so on. For example, it can develop the training project of computer study by 1,000,000 farmers in the province territory, organize ten thousand famous popular science volunteers, and take some 
months to train hundreds of thousands of network popular science model households; it can use information boxcar, the modern distance learning classroom for party member in the countryside, the basic unit party school in the village, the informationization training center and the professional skill training school in the county and the government conference room as the training place. It must be stressed that the innovation of informationization personnel training way in countryside must certainly pay great attention to the actual effect. The informationization construction in countryside is not "the flower trellis", "the achievements project", it is the important safeguard of constructing the new socialist countryside and harmonious society, and is also the request of advancing the countryside reform, increasing farmer's income, constructing the modern standardization agriculture, enhancing the competitiveness of the agriculture.

\subsection{Principle of Participation of International Society and the Relevant Enterprise}

The informationization construction and the personnel training in countryside are the matters of the entire society, and is not merely the business of government department; therefore it needs the participation of the international society, telecommunication operation business and the IT enterprise. The international organization has the superiority about talented person and the construction experience, but the telecommunication and the IT enterprise have the superiority of fund and technology. At present, the European Union is the main international organization that participates in the countryside informationization. It helps to carry on the informationization training in countryside through the Chinese - European Union information society project with the international successful cases and the advanced experience which they have grasped. The telecommunication operation business in China is the concrete executor who provides the informationization infrastructure construction as well as the service, and it affects significantly in informationization construction and the personnel training in countryside. In addition, international famous IT Corporation also may help to carry on the informationization construction and training in countryside. For example, The Microsoft has established the demonstration project of informationization synthesis service experiment site in countryside in 5 provinces, has donated 15 information boxcars, has established 15 information service centers and 6 training bases of comprehensive information, and has trained more than 6000 farmers and the basic unit government cadre. The AMD Corporation plans to construct 7 training centers of synthesis information service in countryside and the first has been established officially in Shandong Province at present.

\subsection{Principle of Positive Participation of Schools and Students}

It should display the superiority of schools and students and enhance the training result in the informationization personnel training in Chinese countryside. Firstly, it must fully mobilize the initiative of the universities, colleges and institutes to participate in the informationization personnel training in countryside. These universities, colleges and institutes have the sufficient multimedia equipment, may take the centralism training spot on weekend and vacation; They have a lot of teachers who have grasped advanced knowledge, some even have pursuesd advanced studies in the information technology, the informationization research aspect. They may play the role of experts or ordinary personnel in training; They have tens of thousands of students, 
which may be competent to be the informationization popular science volunteers after simple training, and some prominent persons also may be competent to be the ordinary personnel. Secondly, it should make full use of the multi-purpose halls and the teacher's microcomputer room resources in general middle school and the school of professional skill training to train farmers by stages and in groups which will guarantee both the centralism training and operation of the computer personally. Considering the slightly shortage of the hardware condition in some middle schools and the school of professional skill training, it will be very good if the government can provide some funds and work together with schools on hardware construction. This can not only guarantee the equipment condition of the informationization personnel training in countryside, but also can enhance the teaching level of the school, in fact it can also enhance the current and latent inhabitant's information accomplishment in countryside.

\subsection{Principle of Unifying the Regular and Non-periodical Training}

In the previous two stages of informationization training in countryside, because it is a new thing to the government personnel or the information officers in countryside, therefore it is necessary for them to grasp the elementary knowledge and the skill through regular training. In the Populace popular stage, the higher authority department also must aim at the new phenomenon, the new question which appears in the informationization construction in countryside, and conducts the centralism training class non-periodically, carries on enhancement training to the government personnel and the information officer in countryside. As for ordinary populace's informationization training, it may unify the big or small information boxcar and all levels of information service station situation, as well as training object time to develop regular or non-periodical training. In addition, it also may carry on non-periodical training to the training object according to the training material which is uploaded in network.

\subsection{Principle of Unifying Centralism Training and Long-Distance Training}

Fixed-point centralism training is the main mode of informationization personnel training in countryside at present, and the long-distance training in network will be the latent way of personnel training from now on. Under the formerly limited condition of network transmission band width, it only could adopt the way of fixed-point centralism training, moreover the centralism training had the superiority of taking the face-to-face communication with the principal speaker, the training effect is better. To the training of informationization staffs who work for the government department as well as the information officer in countryside, it may train mainly in a unified way. Along with the extention of the information infrastructure and the maturity of technology, we have gradually obtained long-distance training condition. Long-distance training has the prominent advantages such as saving the training resources, the broadly popularization, being duplicate trained and so on, it especially suits the populace popular stage which acts as the training terminal, as well as the centralism training that inconvenient because of far away or vast territory with a sparse population area. We should emphasize that it will be able to get up the twice the result with half the effort effect if the long-distance training is carried on auxiliarily by information officer's on-the-spot guidance. 


\section{Conclusion}

The infrastructure construction of countryside informationization in China has begun to take shape, how to enhance the countryside inhabitant's information accomplishment through the personnel training by the effective contract government informationization supplies is becoming a key question of countryside informationization construction in China. With the help of the successful experience of our own country and foreign ones, we propose a training pattern of informationization talent of countryside areas in China which includes the leadership training stage, the information officer training stage and the populace popularizes stage, and specifically point out the main training body, training object and training way on each stage. In the process of realizing this pattern, we must persist to act as circumstances permit with the prominent characteristic principle, the innovation way and the principle of emphasizing the practical effect, the principle of participation among international society and the relevant enterprise, the positive participation of schools and students, regular and non-periodical training unifies principle, centralism training and long-distance training unifies the principle. Thus, the informationization personnel training of countryside area in China can obtain the actual effect, and the effective docking of information supply and demand in countryside area can be realized.

\section{Reference}

1. Li, D.: China Rural Informatization Development Report 2009. Publishing House of Electronics Industry, Beijing (2009) 